\title{
NF-KB signaling mediates acquired resistance after PARP inhibition
}

\author{
Yuko Nakagawa ${ }^{1,2, *}$, Anna S. Sedukhina ${ }^{1, *}$, Naoki Okamoto ${ }^{2}$, Satoi Nagasawa ${ }^{1,3}$, Nao \\ Suzuki ${ }^{2}$, Tomohiko Ohta ${ }^{1}$, Hiroyoshi Hattori ${ }^{4}$, Marta Roche-Molina ${ }^{5}$, Ana J. Narváez ${ }^{6}$, \\ Anand D. Jeyasekharan ${ }^{7}$, Juan A. Bernal' ${ }^{5}$ Ko Sato $^{1}$ \\ ${ }^{1}$ Department of Translational Oncology, St. Marianna University Graduate School of Medicine, Kawasaki 216-8511, Japan \\ ${ }^{2}$ Department of Obstetrics and Gynecology, St. Marianna University Graduate School of Medicine, Kawasaki 216-8511, Japan \\ ${ }^{3}$ Division of Breast and Endocrine Surgery, Department of Surgery, St. Marianna University Graduate School of Medicine, \\ Kawasaki 216-8511, Japan \\ ${ }^{4}$ Laboratory of Advanced Therapy, Department of Hematology and Oncology Research, Clinical Research Center, National \\ Hospital Organization Nagoya Medical Center, Nagoya 460-0001, Japan \\ ${ }^{5}$ Department of Cardiovascular Development and Repair, Centro Nacional de Investigaciones Cardiovasculares (CNIC), \\ Madrid 28029, Spain \\ ${ }^{6}$ MRC Cancer Unit at the University of Cambridge, Hutchison Research Centre, CB2 OXZ, UK \\ ${ }^{7}$ Cancer Science Institute of Singapore, National University of Singapore, Centre for Translational Medicine, 117599, Singapore \\ *These authors have contributed equally to this work
}

Correspondence to:

Ko Sato, e-mail: kosato@marianna-u.ac.jp

Received: August 12, $2014 \quad$ Accepted: December 07, $2014 \quad$ Published: January 13, 2015

\section{ABSTRACT}

PARP inhibitors are a class of promising anti-cancer drugs, with proven activity in BRCA mutant cancers. However, as with other targeted agents, treatment with PARP inhibitors generates acquired resistance within these tumors. The mechanism of this acquired resistance is poorly understood. We established cell lines that are resistant to PARP inhibitor by continuous treatment with the drug, and then used RNA sequencing to compare gene expression. Pathway analysis on the RNA sequencing data indicates that NF-KB signaling is preferentially up-regulated in PARP inhibitorresistant cells, and that knockdown of core components in NF-KB signaling reverses the sensitivity to PARP inhibitor in resistant cells. Of therapeutic relevance, we show that PARP inhibitor-resistant cells are sensitive to an NF-KB inhibitor in comparison to their parental controls. Malignancies with up-regulation of NF-KB are sensitive to bortezomib, a proteasome inhibitor that is currently used in the clinic. We also show that treatment with bortezomib results in cell death in the PARP inhibitor-resistant cells, but not in parental cells. Therefore we propose that up-regulation of NF-kB signaling is a key mechanism underlying acquired resistance to PARP inhibition, and that NF-KB inhibition, or bortezomib are potentially effective anti-cancer agents after the acquisition of resistance to PARP inhibitors.

\section{INTRODUCTION}

Patients with the hereditary breast and ovarian cancer syndrome (HBOCS) commonly have mutations in the key genome stability proteins, BRCA1 and BRCA2. Research over the last decade has yielded a promising therapeutic strategy for $B R C A$ mutant cancers, through the observation that cells mutant for the $B R C A$ genes are exquisitely sensitive to inhibition of the nuclear enzyme poly-adenosine ribose polymerase (PARP), through a synthetic lethal mechanism. These observations have been borne out in early phase clinical trials, with promising activity of PARP inhibitors both in breast and ovarian cancers [1-3]. In ovarian cancer, a recent phase II study has demonstrated a benefit of maintenance PARP inhibition in the management of metastatic ovarian cancers [4]. As with all maintenance therapeutic strategies, the development of resistance to prolonged single agent therapy is inevitable, 
thus necessitating the study of mechanisms of resistance and the development of therapeutic strategies to overcome them. Currently explored mechanisms for acquired resistance to PARP inhibition include 1 . Reversion of the mutation of $B R C A$ gene [5, 6], 2. Disruption of 53BP1 [7], 3. Up-regulation of p-glycoprotein efflux pump [8] and 4. Phosphorylation of ribosomal protein S6 [9]. However, there are no reports to date of a comprehensive screening approach to investigate the mechanism of resistance to PARP inhibition, especially in the context of ovarian cancer where maintenance PARP inhibitor therapy is of clinical benefit.

In this paper, we describe our studies comparing PARP inhibitor resistant and sensitive clones, and show an up-regulation of Nuclear Factor- $\kappa B(N F-\kappa B)$ pathways in the resistant clones. NF- $\kappa \mathrm{B}$ is a complex of transcription factors that consisting of p65 (RelA) and

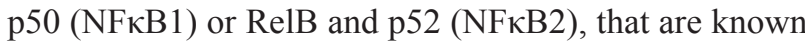
to function in the development of acquired resistance to several other targeted agents [10]. NF- $\kappa \mathrm{B}$ signaling has two major pathways, one is the canonical pathway that mainly modulates cell proliferation, inflammation or anti-apoptosis, and the other one is the non-canonical pathway that mainly controls lymphogenesis and B cell maturation [11]. In the canonical pathway, p65/p50 NF$\kappa \mathrm{B}$ complex are localized in cytoplasm with I $\mathrm{B}$. Stimuli such as infection, cytokines, apoptosis-inducers activate $\mathrm{NF}-\kappa \mathrm{B}$ in canonical pathway. Binding those stimuli to their receptors including tumor necrosis factor receptor (TNFR) or interleukin 1 (IL-1) receptor (IL-1R) activates

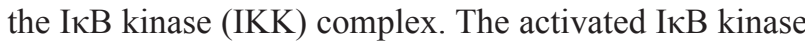
complex phosphorylates I $\mathrm{B}$ and the phosphorylated $\mathrm{I} \kappa \mathrm{B}$ is degraded by $\beta$-TRCP-dependent ubiquitination. This results in nuclear translocation of p65/p50 heterodimer and activates transcription of NF- $\mathrm{NB}$ target genes [10]. In non-canonical pathway, $\mathrm{p} 100$, a precursor of $\mathrm{p} 52$, is a central player. p100 binds to RelB and stays in cytoplasm in non-activated state. Once activated via a binding of ligands including BAFF (B cell activating factor, a family member of TNF) to their receptors, p100 is processed to p52 and RelB/p52 heterodimer is translocated into nucleus to activate transcription of NF- $\kappa \mathrm{B}$ target genes [12].

$\mathrm{NF}-\kappa \mathrm{B}$ inhibition rescues the sensitivity to anticancer drug in chemoresistant cancer cells, through $\mathrm{TNF} \alpha$ mediated apoptosis, and indeed increases tumor regression [13]. Thus, NF- $\mathrm{B}$ plays an important role in chemoresistance, and our paper describes a new role for this pathway in mediating resistance to PARP inhibition as well.

\section{RESULTS}

\section{Establishment of PARP inhibitor resistant clone}

We used UWB1.289 ovarian cancer cells and HCC1937 breast cancer cells as parental cell lines to generate PARP inhibitor-resistant lines. Both the cell lines harbor homozygous mutation of BRCA1. PARP inhibitor-resistant clones (R10 and R100 in UWB1.289 and R500 in HCC1937) were developed independently by repeated exposure to different doses of PARP inhibitor (Olaparib AZD2281, KU-0059436) (10nM, 100nM and $500 \mathrm{nM}$, respectively). To generate PARP inhibitorresistant lines, we have used olaparib (AstraZeneca), a PARP inhibitor that is most advanced in clinical development, and currently in phase III testing [1-4]. For checking resistance to PARP inhibition, we used 2 distinct compounds- olaparib and rucaparib (AG014699); Clovis). While olaparib showed promising results in phase II studies in patients with breast and ovarian cancers having $B R C A$ mutations [4], rucaparib was initially established as a radiosensitizer and to potentiate the effect of temozolamide. Phase II/ III trials are currently underway for both these agents with preliminary results of activity in BRCA mutant cancers [14]. Both the olaparib and rucaparib are bona fide PARP inhibitors and inhibit both PARP1 and PARP2 [14]. Both of the compounds have similar potency in inhibiting PARP catalytic activity [14-16]. The PARP inhibitor-resistant lines show decreased sensitivity to both olaparib and rucaparib, both in UWB1.289 setting- R10/R100 (Figure 1A and 1B) and in the HCC1937 setting- R500 (Figure 1C and 1D).

\section{Validation of reported mechanisms for PARP inhibitor-resistance}

Several mechanisms for acquired resistance to PARP inhibition have been already proposed [5-9]. Therefore, prior to exploring a new mechanism with a comprehensive screening in PARP inhibitor-resistant cells, we have tested whether any of these reported mechanisms were responsible for PARP inhibitor-resistance in our PARP inhibitor-resistant lines. One reported mechanism for acquired resistance to PARP inhibition is a reversion of BRCA1 gene mutation [6]. Therefore we checked the sequence of $B R C A 1$ gene. The mutations of BRCA1 genes are conserved in all the resistant lines (Figure 2A and 2B). Another reported mechanism is disruption of 53BP1 function [7]. Treatment with DNA damaging agents such as camptothecin, a topoisomerase I inhibitor, induces 53BP1 foci formation when 53BP1 is functional [17]. All the parental and PARP inhibitor-resistant UWB1.289 or HCC1937 cells display similar level of induction of 53BP1 foci formation with elevation of $\gamma \mathrm{H} 2 \mathrm{AX}$ signal, a surrogate marker of DNA double strand breaks, in response to camptothecin (Figure 2C-2F and Supplementary Figure 1) [18]. These results suggest that 53BP1 is functional in the PARP inhibitor-resistant lines. Other reports suggest that up-regulation of p-glycoprotein efflux pump Abcbla (as defined by mRNA expression), is a possible mechanism for PARP inhibitor-resistance [8]. mRNA expression of Abcbla in parental and PARP inhibitor-resistant UWB1.289 or HCC1937 cells was investigated and the expression of 

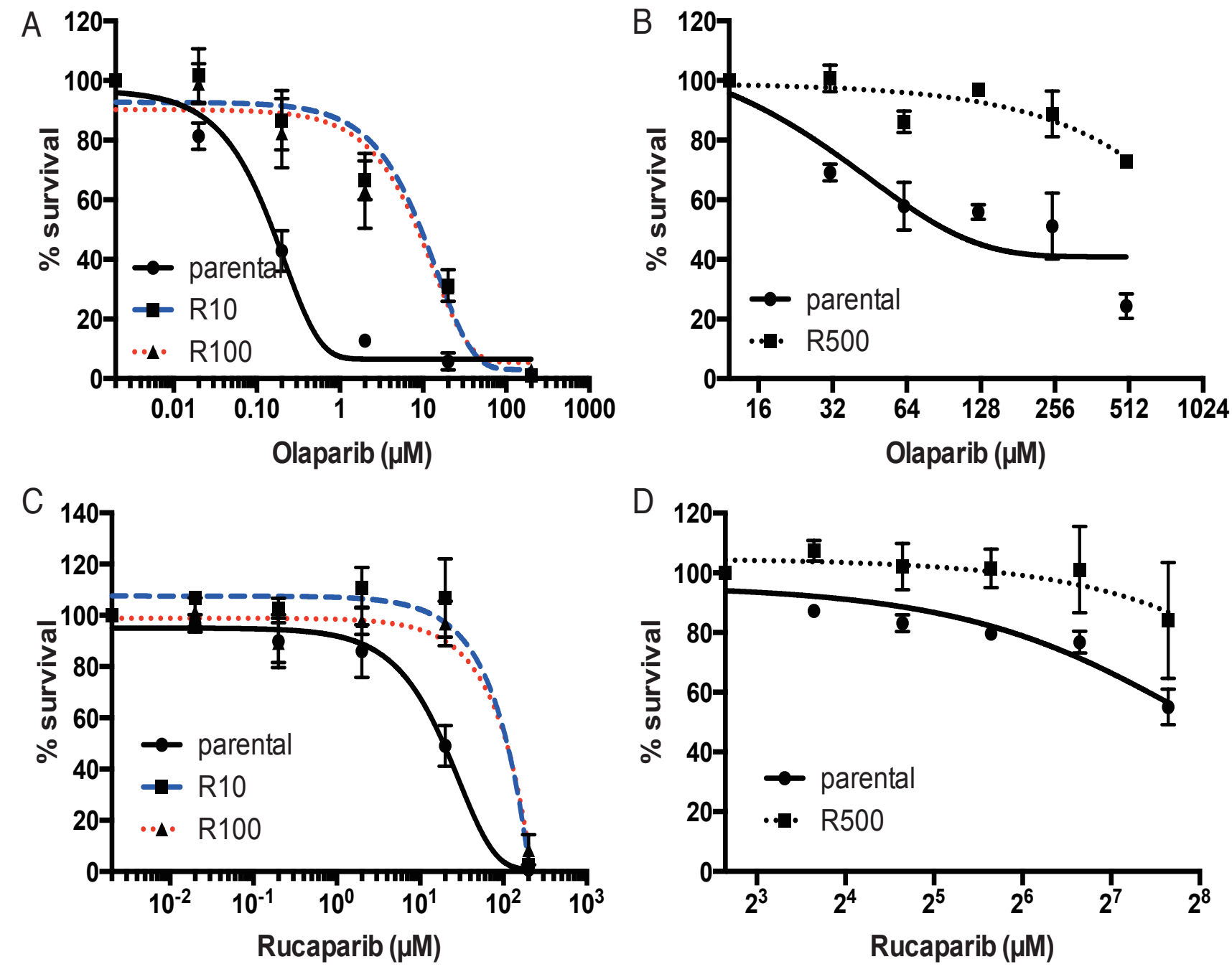

Figure 1: Sensitivity to PARP inhibitor in UWB1.289 cells. Line chart shows the sensitivity to olaparib (A) and (B) or rucaparib (C) and (D) in parental or PARP inhibitor-resistant UWB1.289 cells (A) and (C) and in HCC1937 cells (B) and (D). Error bar shows standard deviation of three independent experiments.

the Abcbla is not altered through the lines (Figure $2 \mathrm{G}$ and $2 \mathrm{H}$ ). An additional mechanism reported for resistance to PARP inhibition is excess phosphorylation of ribosomal protein S6 [9]. However, this is also not applicable in our PARP inhibitor-resistant clones (Figure 2I). Therefore we explored a new mechanism for resistance to PARP inhibition using our clones with acquired resistance, using a comprehensive screening approach.

\section{RNA sequencing to compare PARP inhibitor- resistant and sensitive clones of the ovarian cell line UWB1.289}

We performed whole transcriptome RNA sequencing of cDNA libraries derived from parental UWB1.289, and the PARP inhibitor-resistant clones R10 and R100. We obtained reads to the order of $\sim 13$ million (parental) and $\sim 14$ million (R10 and R100) (Supplementary Figure 2). Among these reads of parental, R10 and R100, 81 to $85 \%$ of them were mapped to human genome GRCh37. Using Rsem and EdgeR analysis, we identified differentially expressed genes (DEGs) among the parental, R10 and R100 (parental vs R10 and parental vs R100) $[19,20]$.

\section{Pathway analysis for acquired resistance to PARP inhibition}

Next we used Ingenuity Pathway Analysis (IPA) to identify the DEGs in the common pathways. IPA is a web-based software to analyze RNA sequencing data to understand relation to large biological systems [21]. In order to obtain meaningful output, we identified DEGs by $\log$ ratio $\geq 2$ and $p$-value $\leq 5.00 \mathrm{E}-02$. In this setting, we identified 118 DEGs (parental vs R10) and 85 DEGs (parental vs R100). IPA with DEGs for parental vs R10 or parental vs R100 shows significant enrichment of genes in category of "Cancer" among the other categories (Supplementary Table 1). To identify the exact pathway 
A

2594delC

A $A A A T G A C A G A A G G C$

WWWhwh wh parental

whunMmulwh R10

whollunwhh R100
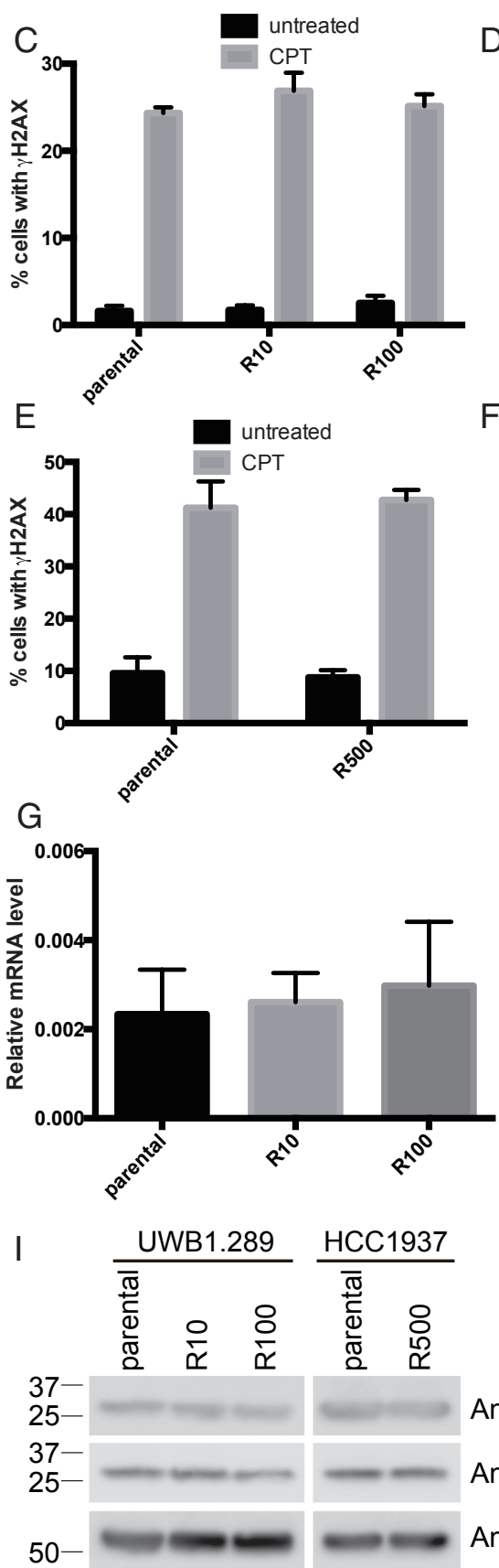

B 5382insC

GACAGGACCCAABGAA

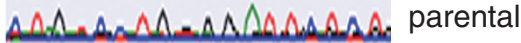

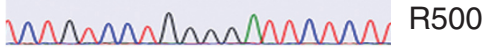
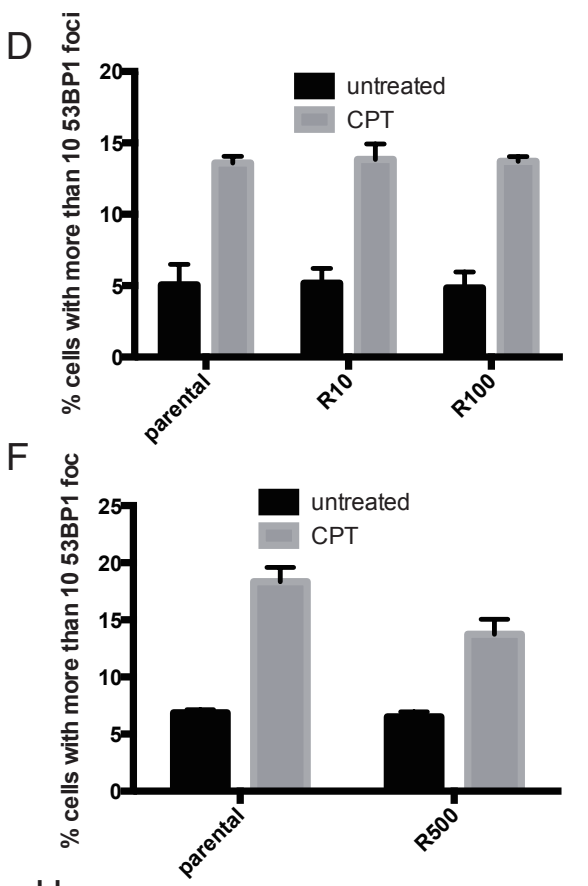

$\mathrm{H}$

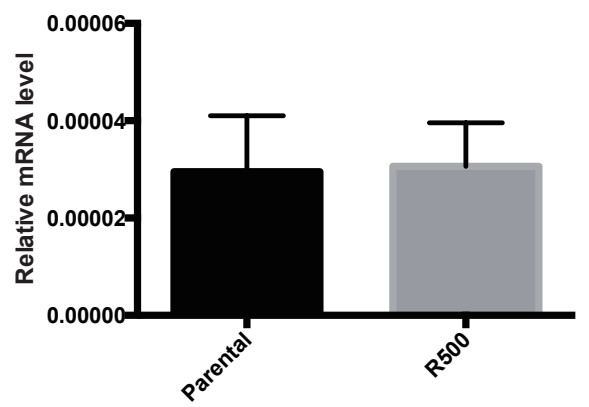

Anti-pS6 (Ser235/236)

Anti-S6

Anti- $\alpha / \beta$-tubulin

Figure 2: Known mechanisms for PARP inhibitor-resistance are not applicable. Direct sequencing of $B R C A 1$ gene in UWB1.289 (A) and HCC1937 (B) are shown. Cells were treated with CPT (camptothecin: 3 $\mu$ M) for 3 hours and stained with antibodies against $\gamma \mathrm{H} 2 \mathrm{AX}$ and 53BP1. Untreated cells were also stained as control. Histogram shows ratio of $\gamma \mathrm{H} 2 \mathrm{AX}$ positive cells in UWB1.289 (C) and in HCC1937 (E) and ratio of cells with more than 10 53BP1 foci in UWB1.289 (D) and in HCC1937 (F). Error bar shows standard deviation of three independent experiments. Histogram shows mRNA expression of Abcbla in parental and PARP inhibitor-resistant UWB1.289 (G) or HCC1937 (H). Error bar shows standard deviation of three independent experiments. Cell lysates from parental or PARP inhibitor-resistant UWB1.289 or HCC1937 cells were subjected for western blotting with indicated antibodies (I). 
in which DEGs are involved, we performed a pathway analysis in IPA. Interestingly, $50 \%$ or above of DEGs involved in both the pathways are genes regulated by NF$\kappa \mathrm{B}$ signaling (4 genes out of 7 DEG in R10 vs parental and 4 genes out of 8 DEGs in R100 vs parental, highlighted in bold letter in Table 1). The DEGs were further validated by network analysis by IPA. This analysis reveals that the top differential networks are "Collagen type 1-" and "TNF family-" in parental vs R10 and parental vs R100, respectively (Table 2). Again both the networks are enriched in genes regulated by $\mathrm{NF}-\kappa \mathrm{B}$ signaling (highlighted in bold letter in Table 2). IPA predicts upstream transcriptional regulators from the global change of mRNA expression. The upstream prediction also reveals enrichment of $\mathrm{NF}-\kappa \mathrm{B}$ regulators such as TNF, STAT3, IL1 and IL1A (Table 3). In summary, IPA analysis predicts that up-regulation of NF- $\kappa \mathrm{B}$ signaling occurs in PARP inhibitor-resistant cells, on the basis of upregulation of genes regulated by $\mathrm{NF}-\kappa \mathrm{B}$ signaling. Aside from the upstream classification of DEGs, we have also tried to identify common downstream signaling pathways that DEGs are involved using the Kyoto Encyclopedia of Genes and Genomes (KEGG) database. While IPA performs analysis with DEGs that are both up-regulated and down-regulated simultaneously, KEGG performs analysis with DEGs either up- or down-regulated. Therefore we picked up up-regulated DEGs defined as $\log$ ratio $\geq 1.5$ and $p$-value $\leq 5.00 \mathrm{E}-02$ for analysis with KEGG. This threshold generates 307 and 314 DEGs in parental vs R10 and parental vs R100, respectively. This analysis revealed that pathways of cytokine-cytokine receptor interaction and cell adhesion molecules (CAMs) are significantly enriched (Table 4). In particular, cytokines and chemokines that are upstream effectors as well as downstream products of NF- $\kappa \mathrm{B}$ signaling, such as IL1 $\beta$ and CCL20, are up-regulated in PARP inhibitor-resistant cells (both in R10 or R100) compared to the parental. These results suggest that NF- $\mathrm{KB}$ pathway is preferentially activated in PARP inhibitor-resistant cells.

\section{$\mathrm{NF- \kappa B}$ signaling is up-regulated in resistant cells}

To confirm that NF- $\kappa \mathrm{B}$ signaling is up-regulated in PARP inhibitor-resistant cells, we performed quantitative Reverse Transcription-Polymerase Chain Reaction (RTPCR) to measure upstream effectors and downstream transcription products of NF- $\kappa \mathrm{B}$ signaling. From IPA and KEGG analysis, we selected a panel of genes involved in TNF $\alpha$ signaling and NF- $\mathrm{BB}$ signaling including TNF receptor family, TNF ligands superfamily members, antiapoptotic genes, and genes that stimulate inflammatory response such as Toll-like receptor family, cytokines, chemokines and p38, an activator of NF- $\kappa \mathrm{B}$ through STAT3 activation (see Supplementary Table 2). Almost all these genes are indeed increased in both the PARP inhibitor-resistant cells (R10 and R100) compared to parental UWB1.289 cells (Figure 3A). RT-PCR shows almost the same agreement with RNA sequencing

Table 1: Top "Canonical Pathways" from the RNA-seq by IPA

\begin{tabular}{|c|c|c|c|}
\hline \multicolumn{4}{|l|}{ Parental vs. R10 } \\
\hline Biological process & $p$-value & Ratio & $\begin{array}{l}\text { Contributing genes in } \\
\text { dataset }\end{array}$ \\
\hline $\begin{array}{l}\text { Hepatic Fibrosis / Hepatic } \\
\text { Stellate Cell Activation }\end{array}$ & $1.4 \mathrm{E}-04$ & $\begin{array}{l}7 / 197 \\
(0.036)\end{array}$ & $\begin{array}{l}\text { CCL2 }(2.824), \\
\text { COL1A2 (4.786), } \\
\text { IGFBP5 (3.739), } \\
\text { MYH14 (6.017), MYL2 } \\
\text { (3.343), NGFR (2.696), } \\
\text { TNFSF18 (2.427) }\end{array}$ \\
\hline
\end{tabular}

\section{Parental vs. R100}

\begin{tabular}{|c|c|c|c|}
\hline Biological process & $p$-value & Ratio & $\begin{array}{l}\text { Contributing genes in } \\
\text { dataset }\end{array}$ \\
\hline $\begin{array}{l}\text { Agranulocyte Adhesion and } \\
\text { Diapedesis }\end{array}$ & $9.14 \mathrm{E}-07$ & $8 / 189(0.042)$ & $\begin{array}{l}\text { CCL2 (2.989), CCL20 } \\
\text { (3.293), CDH5 (2.123), } \\
\text { IL36G (2.719), MMP7 } \\
\text { (2.409), MYH14 } \\
\text { (4.215), MYL2 (2.390), } \\
\text { SELL (2.407) }\end{array}$ \\
\hline
\end{tabular}

Genes involved directly in NF- $\kappa \mathrm{B}$ including TNF signaling are shown in bold letter.

The $p$-value was calculated by Fisher's exact test.

The ratio shows the number of DEGs involved in the pathway divided by total number of genes making up that pathway. 
Table 2: Top "Networks" from the RNA-seq by IPA

\begin{tabular}{|c|c|c|c|}
\hline \multicolumn{4}{|l|}{ Parental vs. R10 } \\
\hline Molecules in network & Score & Focus Molecules & $\begin{array}{l}\text { Top disease and } \\
\text { functions }\end{array}$ \\
\hline $\begin{array}{l}\text { ADAMTS5, Alp, Alpha, } \\
\text { catenin, Atrial Natriuretic } \\
\text { Peptide, BSCL2, Cadherin, } \\
\text { CDH4, CDH5, CDH11, Cg, } \\
\text { CNN1, Collagen type I, } \\
\text { Collagen(s), DGKI, ERK1/2, } \\
\text { Fibrin, FMOD, GDF6, } \\
\text { HSD3B7, IGFBP5, KRT17, } \\
\text { Laminin, MSX1, NPR1, } \\
\text { NPR3, PDGFBB, Secretase } \gamma, \\
\text { STEAP4, SULF1, TGFß, } \\
\text { THY1, TLL1, TNFAIP6, } \\
\text { VCAN, Wnt }\end{array}$ & 42 & 21 & $\begin{array}{l}\text { Cell Morphology, } \\
\text { Carbohydrate } \\
\text { Metabolism, } \\
\text { Drug Metabolism }\end{array}$ \\
\hline
\end{tabular}

Parental vs. R100

\begin{tabular}{|c|c|c|c|}
\hline Molecules in network & Score & Focus Molecules & $\begin{array}{l}\text { Top disease and } \\
\text { functions }\end{array}$ \\
\hline $\begin{array}{l}\text { Alp, Alphacatenin, Cadherin, } \\
\text { CCL20, CD3, CDH4, CDH11, } \\
\text { CEACAM1, Collagen(s), } \\
\text { DDC, DGKI, ERK1/2, } \\
\text { Fibrin, FMOD, GDF6, } \\
\text { IFNy, IGFBP5, IL1, IL36G, } \\
\text { Laminin, LGALS9, Mek, } \\
\text { Mmp, POSTN, SELL, Sos, } \\
\text { STEAP4, SULF1, TGF及, } \\
\text { TNF(family), TNF receptor, } \\
\text { TNFAIP6, TNFSF18, } \\
\text { TRAF1, VCAN }\end{array}$ & 40 & 19 & $\begin{array}{l}\text { Carbohydrate } \\
\text { Metabolism, } \\
\text { Drug Metabolism, } \\
\text { Small Molecule } \\
\text { Biochemistry }\end{array}$ \\
\hline
\end{tabular}

Genes involved directly in NF- $\kappa \mathrm{B}$ including TNF signaling are shown in bold letter.

The score indicates reliability of the network that DEGs are involved ( $<20$ : less reliability and $>40$ : high reliability). The score is calculated based on the hypergeometric distribution and is a negative log of the $p$-value $(\operatorname{score}=-\log 10(p$-value)).

data, which is $95 \%$ similarity (19 of 20 genes). We also attempted to validate these findings using the breast HCC1937 cell lines (parental and R500). Interestingly, while the mRNA of TNF ligands superfamily members, p38, cytokines and chemokines are increased in R500 compared to parental cells, TNF-receptor family members, anti-apoptotic genes or genes that stimulate inflammatory response are not altered in the resistant cells compared to parental (Figure 3B). However $70 \%$ of the list of the genes involved in $\mathrm{NF}-\kappa \mathrm{B}$ signaling increases the expression in PARP inhibitor-resistant cells. These results suggest that NF- $\kappa B$ signaling is up-regulated in PARP inhibitor resistant cells.

In canonical NF- $\kappa \mathrm{B}$ signaling, to activate the transcription of target genes, the p65/p50 subunits of $\mathrm{NF}-\kappa \mathrm{B}$ are translocated into the nucleus [10]. Therefore we measured nuclear retention of p65 in parental or resistant cells, using quantitative high content microscopy. Prior to the experiment, we checked the quality of the anti-p65 antibody and the quantitative high content microscopy. For the quality check of the antibody, p65 was knocked down using siRNA in UWB1.289 cells and the cells were stained with the anti-p65 antibody. The signal of p65 is significantly reduced by the siRNA for p65 (Supplementary Figure 3A). We proceeded to measure the nuclear-cytoplasmic ratio of p65 using NucTrans.V4 algorithm in the cellomics HCS system. For a quality check of our quantitative high content microscopy protocols, the effect of a stimulator and an inhibitor of $N F-\kappa B$ signaling were measured. TNF $\alpha$ is used as a stimulator and BAY $11-7082$, an IKK $\alpha$ inhibitor is used as an inhibitor of the signal [22]. Indeed, TNF $\alpha$ increases nuclear retention of p65, as defined by our protocol, and the effect of TNF $\alpha$ is inhibited by treatment with BAY 11-7082 (Supplementary 
Table 3: Top 5 "Upstream regulators" from the RNA-seq by IPA

\begin{tabular}{|c|c|c|c|}
\hline \multicolumn{4}{|l|}{ Parental vs. R10 } \\
\hline Upstream Regulator & Activation z-score & $p$-value of overlap & $\begin{array}{l}\text { Target molecules in } \\
\text { dataset }\end{array}$ \\
\hline Tretinoin & 2.928 & $9.49 \mathrm{E}-04$ & $\begin{array}{l}\text { ADAMTS5, ALDH1A2, } \\
\text { CCL2, CDH5, } \\
\text { COL1A2, CYP4B1, } \\
\text { FAM153A/FAM153B, } \\
\text { FOLR2, IGFBP5, } \\
\text { KITLG, LGALS9, } \\
\text { LY6E, MYL2, POSTN, } \\
\text { PTF1A, RARRES2, } \\
\text { TNFAIP6 }\end{array}$ \\
\hline TNF & 2.814 & $3.12 \mathrm{E}-03$ & $\begin{array}{l}\text { ADAMTS5, CCL2, } \\
\text { CDH11, CNN1, } \\
\text { COL1A2, DSC3, } \\
\text { IGFBP5, KITLG, } \\
\text { LGALS9, NGFR, } \\
\text { NNMT, P2RY6, } \\
\text { POSTN, RARRES2, } \\
\text { STEAP4, THY1, } \\
\text { TNFAIP6 } \\
\end{array}$ \\
\hline IFNG & 2.442 & $3.17 \mathrm{E}-02$ & $\begin{array}{l}\text { BST1, CCL2, CECR1, } \\
\text { COL1A2, KITLG, } \\
\text { KRT17, LGALS9, } \\
\text { LY6E, MX2, P2RY6, } \\
\text { THY1, TNFAIP6 }\end{array}$ \\
\hline Decitabine & 2.138 & 7.20E-04 & $\begin{array}{l}\text { ALDH1A2, CDH11, } \\
\text { CDH4, COL1A2, } \\
\text { CYP4B1, KRT75, } \\
\text { NPTX1, TLL1, VCAN } \\
\end{array}$ \\
\hline STAT3 & 1.982 & $2.24 \mathrm{E}-03$ & $\begin{array}{l}\text { CCL2, CDH5, } \\
\text { COL1A2, FLRT3, } \\
\text { IGFBP5, KRT17, MX2, } \\
\text { VCAN }\end{array}$ \\
\hline
\end{tabular}

Parental vs. R100

\begin{tabular}{|c|c|c|c|}
\hline Upstream Regulator & Activation z-score & $p$-value of overlap & $\begin{array}{l}\text { Target molecules in } \\
\text { dataset }\end{array}$ \\
\hline TNF & 2.894 & $3.81 \mathrm{E}-05$ & $\begin{array}{l}\text { CCL2, CCL20, CDH11, } \\
\text { CNN1, COL1A2, } \\
\text { DSC3, IGFBP5, IL36G, } \\
\text { LGALS9, MMP7, } \\
\text { NGFR, NNMT, P2RY6, } \\
\text { POSTN, STEAP4, } \\
\text { TNFAIP6, TRAF1 }\end{array}$ \\
\hline IFNG & 2.645 & $1.89 \mathrm{E}-03$ & $\begin{array}{l}\text { CCL2, CCL20, } \\
\text { CEACAM1, COL1A2, } \\
\text { IL36G, LGALS, LY6E, } \\
\text { MX2, P2RY6, SELL, } \\
\text { TNFAIP6, TNFRSF14 }\end{array}$ \\
\hline
\end{tabular}

(Continued) 
Parental vs. R100

\begin{tabular}{|c|c|c|c|}
\hline Upstream Regulator & Activation z-score & $p$-value of overlap & $\begin{array}{l}\text { Target molecules in } \\
\text { dataset }\end{array}$ \\
\hline poly rI:rC-RNA & 2.538 & 7.87E-04 & $\begin{array}{l}\text { CCL2, CCL20, } \\
\text { LGALS9, LY6E, } \\
\text { TNFAIP6, TRAF1, } \\
\text { TRIM6-TRIM34 }\end{array}$ \\
\hline IL1 & 2.509 & $3.68 \mathrm{E}-07$ & $\begin{array}{l}\text { CCL2, CCL20, } \\
\text { CEACAM1, DDC, } \\
\text { GCK, MMP7, NGFR, } \\
\text { SELL, TNFAIP6, } \\
\text { VCAN }\end{array}$ \\
\hline IL1A & 2.367 & $1.18 \mathrm{E}-04$ & $\begin{array}{l}\text { CCL2, CCL20, } \\
\text { IGFBP5, IL36G, } \\
\text { LGALS9, P2RY6 }\end{array}$ \\
\hline
\end{tabular}

Genes involved directly in NF- $\kappa \mathrm{B}$ including TNF signaling are shown in bold letter.

Activation z-score indicates activation state of transcriptional regulators. This is based on expression of downstream genes. Above/below 1 means activation/inhibition of the transcriptional regulator.

Overlap $p$-value indicates significant overlap between DEGs and a transcriptional regulator that could regulate the DEGs.

Table 4: Top 5 "Upstream regulators" from the RNA-seq by KEGG

\begin{tabular}{l} 
Parental vs. R10 \\
\hline \multicolumn{3}{|c|}{ KEGG pathway } & \multicolumn{3}{c}{$\begin{array}{c}\text { No. of DEG } \\
\text { involved / No. of } \\
\text { genes in pathway }\end{array}$} \\
\begin{tabular}{|l|c|l|l|}
\hline $\begin{array}{l}\text { hsa04514:Cell adhesion } \\
\text { molecules (CAMs) }\end{array}$ & 0.0014 & $7 / 132$ & $\begin{array}{l}\text { CDH5, CDH2, NCAM, NGL1, SELL, SDC, } \\
\text { VCAN }\end{array}$ \\
\hline $\begin{array}{l}\text { hsa05410:Hypertrophic } \\
\text { cardiomyopathy (HCM) }\end{array}$ & 0.0039 & $5 / 85$ & $\begin{array}{l}\text { DHPR, TnC, MYL2, ACE1, } \\
\text { TGF } ~\end{array}$ \\
\hline $\begin{array}{l}\text { hsa04060:Cytokine-cytokine } \\
\text { receptor interaction }\end{array}$ & 0.043 & $9 / 262$ & $\begin{array}{l}\text { CCL20, CCL2, CX3CL1, KITLG, NGFR, SF14, } \\
\text { TNFSF18, TGFB2, IL1R2 }\end{array}$ \\
\hline $\begin{array}{l}\text { hsa04610:Complement and } \\
\text { coagulation cascades }\end{array}$ & 0.086 & $\begin{array}{l}\text { Coagulation factor III (thromboplastin, tissue factor), } \\
\text { complement component 1, subcomponent, proteins } \\
\text { (aopha), serpin peptidase inhibitor clade E (nexin } \\
\text { plasminogen activator inhibitor type 1) member1 }\end{array}$ \\
\hline
\end{tabular}
\end{tabular}

\section{Parental vs. R100}

\begin{tabular}{|c|c|c|c|}
\hline KEGG pathway & $p$-value & $\begin{array}{l}\text { No. of DEG involved / } \\
\text { No. of genes in pathway }\end{array}$ & Contributing genes in dataset \\
\hline $\begin{array}{l}\text { hsa04060:Cytokine-cytokine } \\
\text { receptor interaction }\end{array}$ & $3.13 \mathrm{E}-06$ & $19 / 262$ & $\begin{array}{l}\text { CXCL3, CXCL5, CXCL10, } \\
\text { CXCL1, CCL2, CCL20, IL23A, } \\
\text { CSF2, KITLG, FLT1, TNFSF15, } \\
\text { TNFSF18, SFIIB, NGFR, } \\
\text { SFIB, SF14, SF9, TGFB2, } \\
\text { INHBA }\end{array}$ \\
\hline
\end{tabular}

(Continued) 


\begin{tabular}{|c|c|c|c|}
\hline KEGG pathway & $p$-value & $\begin{array}{l}\text { No. of DEG involved / } \\
\text { No. of genes in pathway }\end{array}$ & Contributing genes in dataset \\
\hline $\begin{array}{l}\text { hsa04070:Phoshatidylinositol } \\
\text { signaling system }\end{array}$ & 0.016 & $6 / 74$ & $\begin{array}{l}\text { Diacylglycerol kinase, iota, } \\
\text { inositol 1,4,5-triphoshate3- } \\
\text { kinaseA, phospholipase C, beta } \\
\text { 1(phosphoinositide-specific), } \\
\text { phospholipase C, delta 1, } \\
\text { synaptojanin 2 }\end{array}$ \\
\hline $\begin{array}{l}\text { hsa00562:Inositol phosphate } \\
\text { matabolism }\end{array}$ & 0.022 & $5 / 54$ & $\begin{array}{l}\text { Inositol 1,4,5-triphoshate3-kinase A, } \\
\text { Phospholipase C, beta } 1 \\
\text { (phosphoinositide-specific), } \\
\text { phospholipase C, delta 1, } \\
\text { synaptojanin } 2\end{array}$ \\
\hline $\begin{array}{l}\text { hsa04512:ECM-receptor } \\
\text { interaction }\end{array}$ & 0.026 & $6 / 84$ & $\begin{array}{l}\text { Collagen type1 alpha2, Reelin, } \\
\text { THBS, Syndecan, CD47, } \\
\text { Collagen Type VI alpha } 1\end{array}$ \\
\hline hsa04510:Focal adhesion & 0.048 & $9 / 201$ & $\begin{array}{l}\text { Baculoviral IAP repeat- } \\
\text { containing } 3 \text {, collagen type1 } \\
\text { alpha2, collagen type VI alpha1, } \\
\text { fms-related tyrosine kinase, } \\
\text { myosine light chain kinase, } \\
\text { myosine light chain 2, } \\
\text { Platelet derived growth factor D, } \\
\text { reelin, thrombospondinl }\end{array}$ \\
\hline $\begin{array}{l}\text { hsa04062:Chemokine } \\
\text { signaling pathway }\end{array}$ & 0.080 & $8 / 187$ & $\begin{array}{l}\text { CCL2, CCL20, CXCL10, } \\
\text { CXCL3, CXCL5, CX3CL1, } \\
\text { adenylate cyclase4, } \\
\text { phospholipase C beta } \\
\text { (phosphoinositide-specific) }\end{array}$ \\
\hline
\end{tabular}

Figure $3 \mathrm{~B}$ and $3 \mathrm{C}$ ). Therefore, we have performed further experiments using these settings. In UWB1.289 cells, 7.5 percent of cells have nuclear accumulation of p65 in parental cells. In contrast, $\sim 15.2$ or $\sim 13.2$ percent of cells have accumulated p65 in nucleus in resistant R10 or R100 cells (Figure 3C and Supplementary Figure 4A). Similar results are observed in HCC1937. There is more p65 in nucleus in resistant R500 cells than in parental cells ( $\sim 4.1$ percent $v s . \sim 0.6$ percent, respectively) (Figure 3D and Supplementary Figure 4B). Furthermore, we measured $\mathrm{NF}-\kappa \mathrm{B}$ activation with NF- $\mathrm{kB}$ responsive luciferase reporter gene assay. TNF $\alpha$ induces luciferase activity and the effect of the TNF $\alpha$ is diminished by treatment with BAY 11-7082 (Supplementary Figure 3D), confirming the validity of this assay. In UWB1.289 cells, PARP inhibitorresistant cells show a more than two fold increase in transcriptional activity ( $\sim 19.5$ in parental to $\sim 59.1$ or $\sim 43$ in R10 or R100 respectively) (Figure 3E). In HCC1937 cells, R500 shows almost 3 fold increase compared to parental cells ( 43.7 in parental to $\sim 124.3$ in R500) (Figure 3F). Thus these results suggest that at least a subset of
$\mathrm{NF}-\kappa \mathrm{B}$ signaling is indeed up-regulated in PARP inhibitorresistant cells. Finally, we confirm the effect role of NF- $\kappa B$ signaling in mediating PARP inhibition by knockdown of $\mathrm{p} 65$, a central component in NF- $\mathrm{KB}$ signaling in sensitivity to PARP inhibitor. Strikingly, reduction of p65 reverses the sensitivity to PARP inhibitor in PARP inhibitor-resistant lines both in UWB1.289 and HCC1937 (Figure 3G-3J).

\section{PARP resistant cells are sensitive to $\mathrm{NF}-\kappa \mathrm{B}$ inhibition, and Bortezomib treatment}

In accordance with a central role for NF- $\kappa \mathrm{B}$ signaling in mediating resistance to PARP inhibitors, we show that the PARP inhibitor-resistant UWB1.289 or HCC1937 clones (R10, R100 and R500) are sensitive to an NF-kB inhibitor BAY 11-7082 compared to the parental cells (Figure 4A and 4B). Bortezomib a proteasome inhibitor, also impacts on the NF- $\kappa B$ pathway through protection of $\mathrm{I} \mathrm{KB} \alpha$ from the proteolysis by ubiquitin proteasome system [23]. Whether bortezomib works as an inhibitor of NF-kB signaling is controversial $[24,25]$, but it has been demonstrated that 
A

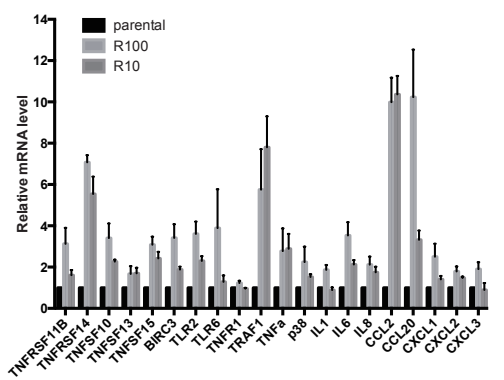

C I

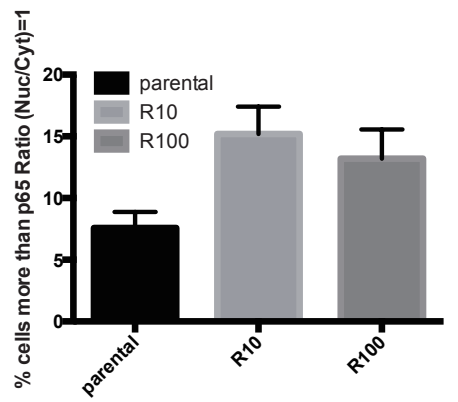

E

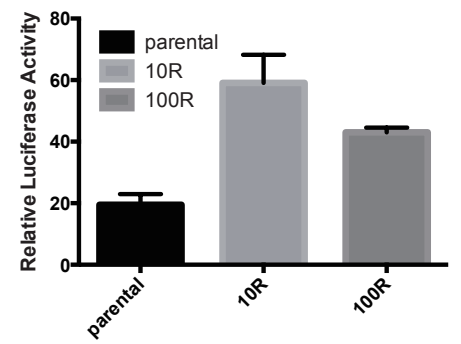

G
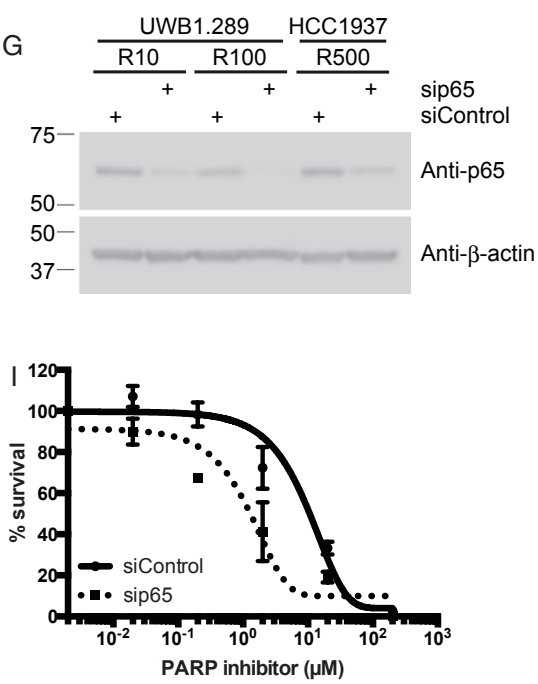

B

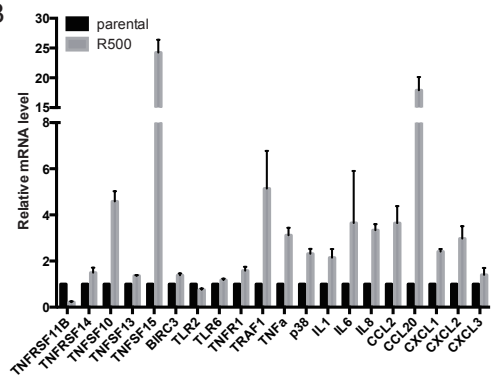

D i
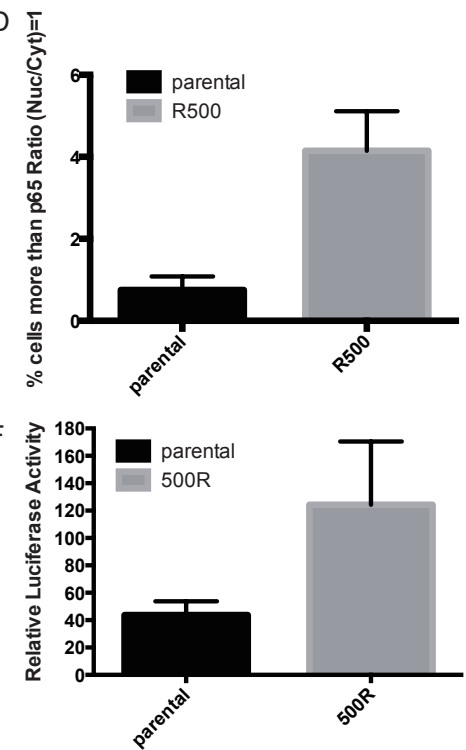

$\mathrm{H}$
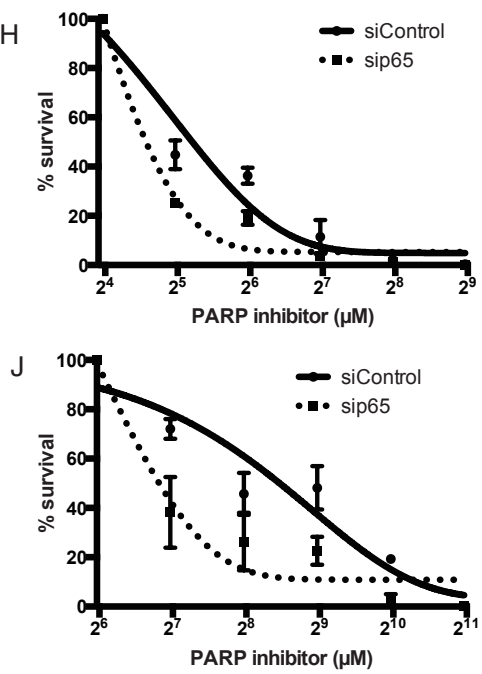

Figure 3: NF-кB is up-regulated in PARP inhibitor-resistant cells. Histogram shows mRNA of indicated genes detected by RT-PCR in parental or PARP inhibitor-resistant UWB1.289 (A) or HCC1937 (B). Error bar shows standard error of three independent experiments. Histogram shows percent of cells with p65 in nucleus in parental or PARP inhibitor-resistant UWB1.289 (C) or HCC1937 cells (D). In C and D, p65 nuclear translocation was presented as \% of cells with intensity contrast: (nuclear intensity - cytoplasmic intensity)/(nuclear intensity + cytoplasmic intensity) $\geq 1$. Error bar shows standard deviation of three independent experiments. Histogram shows Luciferase activity of an NFאB-luciferase reporter plasmid in parental or PARP inhibitor-resistant UWB1.289 (E) or HCC1937 (F) cells, presented relative to the activity of renilla luciferase. Y-axis indicates luciferase activity (relative). Error bar shows standard deviation of three independent experiments. PARP inhibitor-resistant UWB1.289 or HCC1937 cells were transfected with siRNA for p65 or non-targeting siRNA as indicated. Twenty-four hours post transfection, cells were reseeded into 6 well plates for western blotting as well as for clonogenic assay. Forty-eight hours post transfection, cell lysates were subjected for western blotting with indicated antibodies $(\mathbf{G})$, also cells were treated with different concentrations of PARP inhibitor (olaparib) as indicated. Line chart shows sensitivity to PARP inhibitor in transfected resistant R10 (H) and R100 (I) in UWB1.289 or R500 (J) in HCC1937 cells. Error bar shows standard deviation of three independent experiments. 

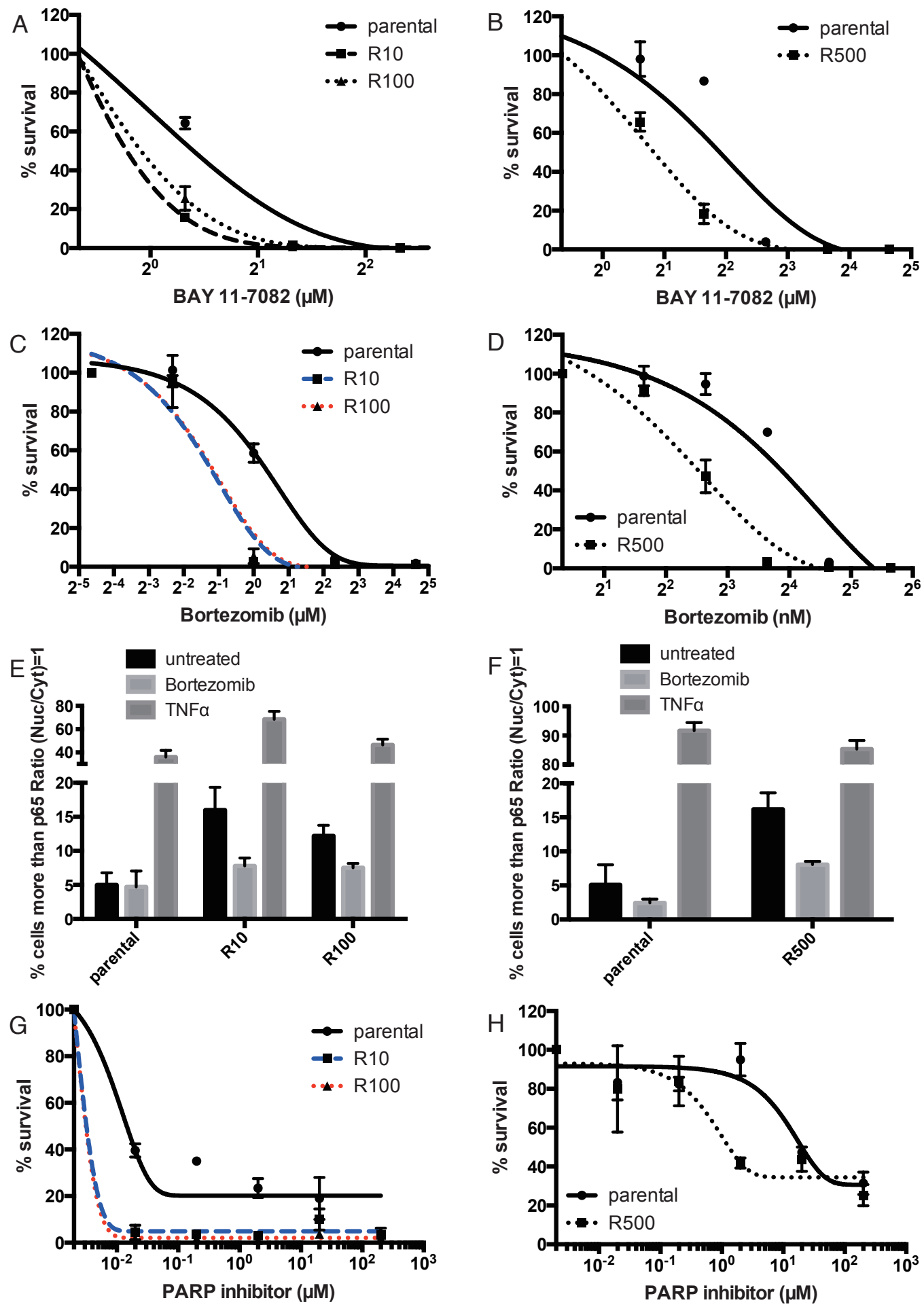

Figure 4: PARP inhibitor-resistant cells are sensitive to NF-кB inhibition. Line chart shows sensitivity to BAY 11-7082 in parental or PARP inhibitor-resistant UWB1.289 (A) or HCC1937 cells (B). Error bar shows standard deviation of three independent experiments. Line chart shows sensitivity to bortezomib in parental or PARP inhibitor-resistant UWB1.289 (C) or HCC1937 cells (D). Error bar shows standard deviation of three independent experiments. The parental and PARP inhibitor-resistant UWB1.289 or HCC1937 cells were treated with bortezomib $(500 \mathrm{pM})$ for 24 hours or TNF $\alpha(100 \mathrm{ng} / \mathrm{ml})$ for 20 minutes and stained with anti-p65 antibody. Untreated cells were also stained as control. Histogram shows percent of cells with p65 in nucleus in parental or PARP inhibitor-resistant UWB1.289 (E) or HCC1937 (F) cells. p65 nuclear translocation was presented as \% of cells with intensity contrast: (nuclear intensity - cytoplasmic intensity)/(nuclear intensity + cytoplasmic intensity) $\geq 1$. Error bar shows standard deviation of three independent experiments. Line chart shows the sensitivity to PARP inhibitor (olaparib) with bortezomib (30nM for UWB1.289 and 500pM for HCC1937) in parental or resistant UWB1.289 (G) or HCC1937 (H) Error bar shows standard deviation of three independent experiments. 
bortezomib kills cells with up-regulated NF- $\kappa$ B signaling [26]. As the drug is currently approved by the U.S. Food and Drug Administration for clinical use in the treatment of Multiple Myeloma [27], we checked the cellular sensitivity to bortezomib in UWB1.289 or HCC1937 cells. As expected, bortezomib kills PARP inhibitor-resistant cells derived from UWB1.289 preferentially compared to the parental cells (Figure 4C). This effect is also observed in HCC1937 (Figure 4D). We further tested whether bortezomib inhibits or activates NF- $\kappa \mathrm{B}$ signaling in the PARP inhibitor-resistant cells. Bortezomib indeed decreases nuclear retention of p65 preferentially in PARP inhibitor-resistant lines compared to parental UWB1.289 (Figure 4E) or HCC1937 cells (Figure $4 \mathrm{~F}$ ), suggesting that it seems to inhibit NF- $\kappa \mathrm{B}$ signaling in the setting of acquired PARP resistance.

This prompted us to check if bortezomib could be used to reverse the PARP resistant phenotype of our cell lines. The sensitivity to bortezomib in parental and PARP inhibitorresistant clones does not differ up to 200nM in UWB1.289 and 4nM in HCC1937 (Figure 4A and 4B). Therefore the sensitivity to PARP inhibition in conjunction with a low dose of bortezomib (30nM for UWB1.289 and 500pM for HCC1937) was assessed. As expected, bortezomib increases the sensitivity to PARP inhibition in PARP inhibitor-resistant cells preferentially (Figure 4G and $4 \mathrm{H}$ ). These data suggest that inhibition of NF- $\kappa \mathrm{B}$ signaling is an effective therapy for PARP inhibitor-resistant cancers, and that inhibition of NF$\kappa \mathrm{B}$ signaling reverses cellular sensitivity to PARP inhibition in resistant cells.

\section{DISCUSSION}

The mechanism of acquired resistance to PARP inhibitor has been extensively studied and several models have been proposed [5-9]. Because all the mechanisms suggested were not applicable in our resistant lines, we screened an ovarian cancer cell line (which is the most clinically applicable context for continuous PARP inhibitor therapy [4]) by RNA sequencing, and note increased $\mathrm{NF}-\kappa \mathrm{B}$ pathway activation. Interestingly, up-regulation of NF- $\mathrm{B}$ signaling is known to cause acquired resistance to other agents apart from PARP inhibitors [13].

We have shown that mRNA of genes that are involved in $\mathrm{NF}-\kappa \mathrm{B}$ signaling are altered in expression when the cells acquire resistance to PARP inhibition. The precise mechanism by which these NF- $\kappa$ B related mRNAs are up-regulated is not known, and will be the subject of future work in the lab.

$\mathrm{NF}-\kappa \mathrm{B}$ has an anti-apoptotic effect and it has been thought that increased anti-apoptotic effect by up-regulated $\mathrm{NF}-\kappa \mathrm{B}$ signaling plays an important role in acquired resistance [13]. Interestingly, genes that are involved in anti-apoptosis are not up-regulated both in UWB1.289 and HCC1937 in our setting. How up-regulated NF-кB signaling without up-regulation of anti-apoptotic gene serves for the acquired resistance is not known. The information of the exact mechanism may help to develop a better therapy for chemoresistant malignancies.

Finally, we propose inhibition of $N F-\kappa B$ is an effective anti-cancer therapy for malignancies for acquired resistance to PARP inhibition. NF- $\kappa \mathrm{B}$ inhibitors are still not used as practical clinical medicines because of toxicity and specificity [28]. On the other hand, while bortezomib is not a typical NF- $\kappa \mathrm{B}$ inhibitor, it does have a negative influence on the pathway in most contexts, and is clinically approved [27]. Furthermore, co-treatment with bortezomib may allow a reversal of the acquired resistance to PARP inhibition. Further study is needed to develop this idea for clinical use to benefit patients who progress on PARP inhibitor therapy.

\section{MATERIALS AND METHODS}

\section{Cell culture}

UWB1.289 and HCC1937 cells were cultured in RPMI-1640 medium supplemented with $10 \%$ fetal bovine serum and $1 \%$ penicillin-streptomycin at $37^{\circ} \mathrm{C}$.

\section{Generation of PARP inhibitor-resistant clones}

To generate PARP inhibitor-resistant clones, UWB1.289 cells were continuously exposed to different doses of PARP inhibitor (10nM or 100nM). The cells were split every other day for 5 months. In HCC1937, cells were exposed to PARP inhibitor $(500 \mathrm{nM})$. The cells were split every other day for 3 months.

\section{Cell viability assay}

Cells were plated into 6-well plates at a density of 1000 cells per well. Different doses of drugs were added, and the plates were incubated at $37^{\circ} \mathrm{C}$ for a week. Cells were fixed with $75 \%$ methanol in $25 \%$ acetic acid for $5 \mathrm{~min}$, and the plates were dried. Colonies were stained with Lillie's crystal violet ( $2 \mathrm{~g}$ crystal violet, $0.8 \mathrm{~g}$ ammonium oxalate in $100 \mathrm{ml}$ of $80 \%$ ethanol) for $5 \mathrm{~min}$ and subsequently washed with water, dried, and measured by ImageQuant LAS 4000 (GE healthcare).

\section{Genomic DNA collection}

Cells were lysed with $0.5 \%$ NF-40 lysis buffer. Once cells were dissolved, same volume of $100 \%$ phenol TE was added, then centrifuged at maximum speed. Supernatant was collected and same volume of isopropanol was added, and mixed well, then centrifugation. The pellet was washed with $70 \%$ ethanol once and dissolved with appropriate volume of water. 


\section{Direct sequencing of $B R C A 1$ gene}

Direct sequencing was performed by Applied Biosystems 3130 Genetic Analyzer following the protocol as suggested by the manufacturer. Primers for sequencing are CTGGTACTGATTATGGCACTCAGG for UWB1.289 and CTTAAAGTCCCAGCTCTTCCAC for HCC1937.

\section{Immunofluorescence}

Cells were cultured on 96 well plastic plates (BD Falcon). 24 hours later, cells were treated with $3 \mathrm{uM}$ of Camptothecin for 1 hour, when required. The cells were fixed with 4\% PFA in PBS for 15 minutes. Then cells were washed with PBS and permeabilized with $0.2 \%$ Triton-X100 for 5 minutes and blocked with 3\% BSA in PBSt for 15 minutes. Followed by blocking, cells were incubates with primary antibodies for 1 hour at room temperature, then cells were washed three times with PBSt followed by incubated with secondary antibodies for 30 minutes at room temperature. Nuclei were stained with Hoechest 33342 (1:1000, Invitrogen) for 15 minutes and analyzed by Cellomics Cellinsight high content screening reader (Thermo Scientific).

\section{Antibodies}

The antibodies and dilution used in this study were: Anti- $\gamma \mathrm{H} 2 \mathrm{AX}$ (Ser139) antibody (Millipore, 05-636, 1:1000); Anti-53BP1 antibody (Novus Biologicals, NB100-304, 1:1000); Anti-ribosomal protein S6 antibody (Cell Signaling Technology, 2217, 1:1000); Anti-phospho-ribosomal protein S6 (Ser235/236) antibody (Cell Signaling Technology, 4858, 1:2000); and Anti- $\alpha /$ $\beta$-tubulin antibody (NeoMarkers, DM1A, 1:5000); Anti-p65 antibody (Cell Signaling Technology, 8242, 1:500 for IF and 1:1000 for WB); Anti- $\beta$-actin (SIGMA, AC-15, 1:1000); secondary antibodies (Alexa Flour, 1:1000).

\section{Real-time reverse transcription polymerase chain reaction}

Quantitative real-time RT-PCR of transcript levels in UWB1.289 and HCC1937 were performed using a StepOnePlus ${ }^{\mathrm{TM}}$ real time PCR system (applied biosystems, Warrington, UK). Total RNA was extracted using an RNeasy Mini Kit (QIAGEN Sciences, Valencia, CA), and cDNA was synthesized using a PrimeScriptTM RT Master Mix (Takara, Tokyo, Japan) according to the manufacturer's protocol. Real-time PCR was performed using Power SYBR Green PCR Master Mix (applied biosystems) as follows: $15 \mathrm{~min}$ at $95 \mathrm{C}$ and then 45 cycles of $15 \mathrm{sec}$ at $95 \mathrm{C}$ and $60 \mathrm{sec}$ at $60 \mathrm{C}$. Data were analyzed by the cycle threshold method to determine the fold changes in expression. Relative abundance of specific genes was normalized to those of GAPDH levels. Primers sequences used in Figure 3 are presented in Supplementary Table 2. Primers for Abcbla gene are GAACAAGGGGAGCACCAAC (forward primer) and TGCTTTCCTCAAAGAGTTTCTG (reverse primer).

\section{Western blots}

UWB1.289 and HCC1937 cells were transfected with siRNA using Lipofectamin RNAiMAX (Life Technologies) transfection reagent following manufacturer protocol. RNAi for p65 and non-targeting siRNA were purchased from Cell Signaling Technology. Western blots were done as described previously [29], briefly 48 hours after transfection, cells were lysed with $0.5 \% \mathrm{NP}-40$ lysis buffer $(50 \mathrm{mM}$ Tris- $\mathrm{HCl} \mathrm{pH} 7.5,150 \mathrm{mM} \mathrm{NaCl}, 0.5 \% \mathrm{NP}-$ 40, $50 \mathrm{mM} \mathrm{NaF}, 1 \mathrm{mM}$ DTT, $1 \mathrm{mM} \mathrm{Na} \mathrm{VO}_{4}$, complete protease inhibitor cocktail (Roche) and 1mM PMSF) and resolved by SDS-PAGE

\section{RNA quality control and library preparation}

Total RNA was quantified and purity checked using a NanoDrop ND-1000 (Thermo Scientific, Waltham, MA, USA). RNA integrity was verified using an Agilent 2100 Bioanalyzer (Agilent Technologies, Santa Clara, CA, USA). Subsequently, $500 \mathrm{ng}$ of total RNA were used with the TruSeq RNA Sample Preparation v2 Kit (Illumina, San Diego, CA) to construct index-tagged cDNA libraries. Libraries were quantified using a Quant-iT ${ }^{\mathrm{TM}}$ dsDNA HS assay with the Q-bit fluorometer (Life Technologies, Carlsbad, California). Average library size and the size distribution were determined using a DNA 1000 assay in an Agilent 2100 Bioanalyzer. Libraries were normalized to $10 \mathrm{nmol} / \mathrm{L}$ using Tris-Cl $10 \mathrm{mmol} / \mathrm{L}$, pH8.5 with $0.1 \%$ Tween 20.

\section{RNA sequencing and data analysis}

Total RNA derived from PARP inhibitor-resistant or parental UWB1.289 cells were isolated by trizol and whole transcriptome analysis was performed. The sample of each cells were technical replicated. Cutadapt was used to trim Illumina adapters and to remove those reads that were too short. Filtered reads were then aligned with Rsem against the GRCh37.p11 collection of transcripts. Each RefSeq gene's expression was summarized and normalized using EdgeR bioconductor R package. Differentially expressed genes were identified with coverage (more than 1 at least one sample) and fold change (more than 1.5). Biological functions and network analysis of differentially expressed genes were performed using KEGG that is included in DAVID gene ontology (http://david.abcc.ncifcrf.gov/) as well as Ingenuity Pathway Analysis (IPA) (http://www. ingenuity.com/) [30,31]. 


\section{Ingenuity Pathway Analysis (IPA)}

RNA sequencing data were analyze by IPA software in terms of search common networks and canonical pathways. Significance of the networks and canonical pathways were tested by the $p$-value. Top networks show associative networks based on a score. The statistically significance were considered by score $\geq 2$.

\section{Plasmids}

For NF- $\kappa B$ activation assays in UWB1.289 and HCC1937 cells, we used an NF- $\mathrm{KB}$ site-containing luciferase reporter plasmid. For normalization and control, we used a luciferase reporter without the NF- $\mathrm{kB}$ sitecontaining and a Renilla luciferase for normalization. All the constructs are under pRL-TK backbone vectors (A gift from Dr. Grahame McKenzie).

\section{Luciferase assay}

$5 \times 10^{6}$ of UWB1.289 cells or $3 \times 10^{6}$ of HCC1937 cells were transfected with $14 \mathrm{ug}$ of NF- $\mathrm{kB}$ firefly luciferase reporter vector and $1 \mu \mathrm{g}$ of $\mathrm{pRL}-\mathrm{TK}$ renilla luciferase vector. For control, UWB1.289 or HCC1937 cells were transfected with $14 \mu \mathrm{g}$ of pGL3 basic firely luciferase reporter vector with $1 \mu \mathrm{g}$ of $\mathrm{pRL}-\mathrm{TK}$ renilla luciferase vector. Transfections were carried out with Cell Line Nucleofector Kit V in Nucleofector (Lonza) using program A-023. Cells were cultured in $2 \mathrm{ml}$ of RPMI-1640 medium in a 12-well plate. Luciferase assay was performed using Dual Luciferase Assay kit (Promega) per manufactures instructions. Luciferase activity was measured at 48 hours post transfection. For measurement, $30 \mu \mathrm{l}$ of each renilla and firefly substrate were injected into $30 \mu \mathrm{l}$ out of $120 \mu \mathrm{l}$ of cell lysate. Luciferase signals of firefly were divided by renilla signals and standard error of the mean (SEM) of triplicated experiments was calculated.

\section{Statistical analysis}

All the statistical analyses have been done by graphpad prism. The statistically significance were considered by $p<0.05$.

\section{ACKNOWLEDGMENT}

We thank Dr. Grahame McKenzie for the kind gift of plasmids for luciferase assay. This work was supported by St. Marianna University Grant.

\section{Conflict of interest}

The authors declare no conflict of interest.

\section{REFERENCES}

1. Fong PC, Boss DS, Yap TA, Tutt A, Wu P, MerguiRoelvink M, Mortimer $\mathrm{P}$, Swaisland $\mathrm{H}$, Lau A, O'Connor MJ, Ashworth A, Carmichael J, Kaye SB, Schellens JH, de Bono JS. Inhibition of poly(ADP-ribose) polymerase in tumors from BRCA mutation carriers. The New England journal of medicine. 2009; 361:123-134.

2. Yap TA, Sandhu SK, Carden CP, de Bono JS. Poly(ADPribose) polymerase (PARP) inhibitors: Exploiting a synthetic lethal strategy in the clinic. CA: a cancer journal for clinicians. 2011; 61:31-49.

3. Gelmon KA, Tischkowitz M, Mackay H, Swenerton K, Robidoux A, Tonkin K, Hirte H, Huntsman D, Clemons M, Gilks B, Yerushalmi R, Macpherson E, Carmichael J, Oza A. Olaparib in patients with recurrent high-grade serous or poorly differentiated ovarian carcinoma or triple-negative breast cancer: a phase 2, multicentre, open-label, nonrandomised study. The lancet oncology. 2011; 12:852-861.

4. Ledermann J, Harter P, Gourley C, Friedlander M, Vergote I, Rustin G, Scott C, Meier W, Shapira-Frommer R, Safra T, Matei D, Macpherson E, Watkins C, Carmichael J, Matulonis U. Olaparib maintenance therapy in platinumsensitive relapsed ovarian cancer. The New England journal of medicine. 2012; 366:1382-1392.

5. Edwards SL, Brough R, Lord CJ, Natrajan R, Vatcheva R, Levine DA, Boyd J, Reis-Filho JS, Ashworth A. Resistance to therapy caused by intragenic deletion in BRCA2. Nature. 2008; 451:1111-1115.

6. Norquist B, Wurz KA, Pennil CC, Garcia R, Gross J, Sakai W, Karlan BY, Taniguchi T, Swisher EM. Secondary somatic mutations restoring BRCA1/2 predict chemotherapy resistance in hereditary ovarian carcinomas. J Clin Oncol. 2011; 29:3008-3015.

7. Bouwman P, Aly A, Escandell JM, Pieterse M, Bartkova J, van der Gulden H, Hiddingh S, Thanasoula M, Kulkarni A, Yang Q, Haffty BG, Tommiska J, Blomqvist C, Drapkin R, Adams DJ, Nevanlinna H, et al. 53BP1 loss rescues BRCA1 deficiency and is associated with triple-negative and BRCAmutated breast cancers. Nature structural \& molecular biology. 2010; 17:688-695.

8. Rottenberg $\mathrm{S}$, Jaspers JE, Kersbergen A, van der Burg E, Nygren AO, Zander SA, Derksen PW, de Bruin M, Zevenhoven J, Lau A, Boulter R, Cranston A, O'Connor MJ, Martin NM, Borst P, Jonkers J. High sensitivity of BRCA1-deficient mammary tumors to the PARP inhibitor AZD2281 alone and in combination with platinum drugs. Proc Natl Acad Sci U S A. 2008; 105:17079-17084.

9. Sun CK, Zhang F, Xiang T, Chen Q, Pandita TK, Huang Y, Hu MC, Yang Q. Phosphorylation of ribosomal protein S6 confers PARP inhibitor resistance in BRCA1deficient cancers. Oncotarget. 2014; 5:3375-3385.

10. Hayden MS, Ghosh S. Shared principles in NF-kappaB signaling. Cell. 2008; 132:344-362. 
11. Hayden MS, Ghosh S. Signaling to NF-kappaB. Genes \& development. 2004; 18:2195-2224.

12. Sun SC. Non-canonical NF-kappaB signaling pathway. Cell research. 2011; 21:71-85.

13. Wang CY, Cusack JC Jr, Liu R, Baldwin AS Jr. Control of inducible chemoresistance: enhanced anti-tumor therapy through increased apoptosis by inhibition of NF-kappaB. Nature medicine. 1999; 5:412-417.

14. Mateo J, Ong M, Tan DS, Gonzalez MA, de Bono JS. Appraising iniparib, the PARP inhibitor that never was - what must we learn? Nature reviews Clinical oncology. 2013; 10:688-696.

15. Ali M, Telfer BA, McCrudden C, O'Rourke M, Thomas HD, Kamjoo M, Kyle S, Robson T, Shaw C, Hirst DG, Curtin NJ, Williams KJ. Vasoactivity of AG014699, a clinically active small molecule inhibitor of poly(ADP-ribose) polymerase: a contributory factor to chemopotentiation in vivo? Clinical cancer research: an official journal of the American Association for Cancer Research. 2009; 15:6106-6112.

16. Murai J, Huang SY, Renaud A, Zhang Y, Ji J, Takeda S, Morris J, Teicher B, Doroshow JH, Pommier Y. Stereospecific PARP trapping by BMN 673 and comparison with olaparib and rucaparib. Molecular cancer therapeutics. 2014; 13:433-443.

17. Rappold I, Iwabuchi K, Date T, Chen J. Tumor suppressor p53 binding protein 1 (53BP1) is involved in DNA damage-signaling pathways. The Journal of cell biology. 2001; 153:613-620.

18. Ayoub N, Jeyasekharan AD, Bernal JA, Venkitaraman AR. HP1-beta mobilization promotes chromatin changes that initiate the DNA damage response. Nature. 2008; 453:682-686.

19. Li B, Dewey CN. RSEM: accurate transcript quantification from RNA-Seq data with or without a reference genome. BMC bioinformatics. 2011; 12:323.

20. Anders S, McCarthy DJ, Chen Y, Okoniewski M, Smyth GK, Huber W, Robinson MD. Count-based differential expression analysis of RNA sequencing data using R and Bioconductor. Nature protocols. 2013; $8: 1765-1786$.

21. Kramer A, Green J, Pollard J Jr., Tugendreich S. Causal analysis approaches in Ingenuity Pathway Analysis. Bioinformatics. 2014; 30:523-530.
22. Fernandez-Majada V, Aguilera C, Villanueva A, Vilardell F, Robert-Moreno A, Aytes A, Real FX, Capella G, Mayo MW, Espinosa L, Bigas A. Nuclear IKK activity leads to dysregulated notch-dependent gene expression in colorectal cancer. Proc Natl Acad Sci U S A. 2007; 104:276-281.

23. Hideshima T, Chauhan D, Richardson P, Mitsiades C, Mitsiades N, Hayashi T, Munshi N, Dang L, Castro A, Palombella V, Adams J, Anderson KC. NF-kappa B as a therapeutic target in multiple myeloma. The Journal of biological chemistry. 2002; 277:16639-16647.

24. Hideshima T, Ikeda H, Chauhan D, Okawa Y, Raje N, Podar K, Mitsiades C, Munshi NC, Richardson PG, Carrasco RD, Anderson KC. Bortezomib induces canonical nuclear factor-kappaB activation in multiple myeloma cells. Blood. 2009; 114:1046-1052.

25. Li C, Chen S, Yue P, Deng X, Lonial S, Khuri FR, Sun SY. Proteasome inhibitor PS-341 (bortezomib) induces calpain-dependent IkappaB(alpha) degradation. The Journal of biological chemistry. 2010; 285:16096-16104.

26. Hideshima T, Richardson P, Chauhan D, Palombella VJ, Elliott PJ, Adams J, Anderson KC. The proteasome inhibitor PS-341 inhibits growth, induces apoptosis, and overcomes drug resistance in human multiple myeloma cells. Cancer research. 2001; 61:3071-3076.

27. Baud V, Karin M. Is NF-kappaB a good target for cancer therapy? Hopes and pitfalls. Nature reviews Drug discovery. 2009; 8:33-40.

28. Gilmore TD, Herscovitch M. Inhibitors of NF-kappaB signaling: 785 and counting. Oncogene. 2006; 25:6887-6899.

29. Sato K, Sundaramoorthy E, Rajendra E, Hattori H, Jeyasekharan AD, Ayoub N, Schiess R, Aebersold R, Nishikawa $H$, Sedukhina AS, Wada $H$, Ohta $T$, Venkitaraman AR. A DNA-damage selective role for BRCA1 E3 ligase in claspin ubiquitylation, CHK1 activation, and DNA repair. Current biology: CB. 2012; 22:1659-1666.

30. Huang da W, Sherman BT, Lempicki RA. Systematic and integrative analysis of large gene lists using DAVID bioinformatics resources. Nature protocols. 2009; 4:44-57.

31. Huang da W, Sherman BT, Lempicki RA. Bioinformatics enrichment tools: paths toward the comprehensive functional analysis of large gene lists. Nucleic acids research. 2009; 37:1-13. 